\title{
Differential control of vasomotion by angiotensins in the rostral ventrolateral medulla of hypertensive rats
}

\author{
Patrícia M. Ferreira ${ }^{\mathrm{a}, *}$, Carlos H. Xavier ${ }^{\mathrm{a}}$, Andreia C. Alzamora ${ }^{\mathrm{b}}$, \\ Robson A.S. Santos ${ }^{c}$, Maria J. Campagnole-Santos ${ }^{c}$ \\ a Departamento de Ciências Fisiológicas, Instituto de Ciências Biológicas, Universidade Federal de Goiás, Goiânia, GO, Brazil \\ b Departamento de Ciências Biológicas, Instituto de Ciências Exatas e Biológicas, Universidade Federal de Ouro Preto, MG, Brazil

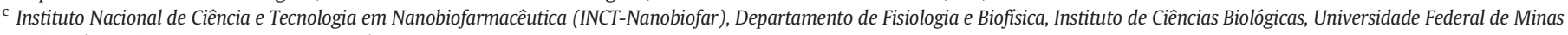 \\ Gerais, Belo Horizonte 31270-901, MG, Brazil
}

\section{A R T I C L E I N F O}

\section{Article history:}

Received 16 April 2015

Received in revised form 25 August 2015

Accepted 8 September 2015

Available online 9 September 2015

\section{Keywords:}

Ang-(1-7)

Ang II

Rostral ventrolateral medulla

Arterial pressure

Vascular blood flow

Spontaneously hypertensive rats

\begin{abstract}
A B S T R A C T
The central and peripheral renin-angiotensin systems are known for playing a key role in cardiovascular control. In the present study, we evaluated the hemodynamic effects produced by nanoinjections of angiotensin II (Ang II) or angiotensin-(1-7) [Ang-(1-7)] into the rostral ventrolateral medulla (RVLM) of adult male normotensive (Wistar-WT) and spontaneously hypertensive rats (SHR). Animals were anesthetized (urethane $1.2 \mathrm{~g} / \mathrm{kg}$ ) and instrumented for recording blood pressure (BP), heart rate (HR) and blood flow (BF) in the femoral, renal or mesenteric arteries. Afterwards, rats were positioned in a stereotaxic and prepared for nanoinjections (100 nl) of saline ( $\mathrm{NaCl} 0.9 \%$ ), Ang-(1-7) (40 ng) or Ang II (40 ng) into the RVLM. The vascular resistance (VR) was calculated by $\triangle \mathrm{MAP} / \triangle \mathrm{BF}$ ratio. In $\mathrm{WT}$, Ang-(1-7) or Ang II caused equipotent pressor effects that were not accompanied by changes in vascular resistance. However, MAP changes were greater in SHR. This strain also showed a concomitant increase in relative vascular resistance $(\triangle \mathrm{VR} / \mathrm{VR}$ baseline $)$ of renal $(0.31 \pm 0.07$ and $0.3 \pm 0.07 \mathrm{vs}$. $0.02 \pm 0.01$; Ang-(1-7), Ang II and Saline, respectively) and mesenteric beds ( $0.3 \pm 0.06$ and $0.33 \pm 0.04$ vs. $0.05 \pm 0.02$; Ang-(1-7), Ang II and saline, respectively). We conclude that Ang II and Ang-(1-7) at the RVLM control the vascular resistance of renal and mesenteric beds during hypertension.
\end{abstract}

(c) 2015 Elsevier Ltd. All rights reserved.

\section{Introduction}

The rostral ventrolateral medulla (RVLM) is a major vasomotor center in the brainstem, containing sympathetic premotor neurons responsible for generating and maintaining vasomotor tone and resting levels of arterial blood pressure. RVLM is under modulatory influence of the renin-angiotensin system (RAS). Several studies demonstrated that some medullary areas are activated by injections of Angiotensin II (Ang II) and Angiotensin (1-7) [Ang-(1-7)](Allen et al., 1988; Alzamora et al., 2002; Andreatta et al., 1988; Fontes et al., 1997, 1994; Li et al., 2012; Muratani et al., 1991, 1993; Silva et al., 1993). In normotensive rats, injections of Ang II or Ang-(1-7) into the RVLM increases arterial pressure and sympathetic nerve activity (Allen et al., 1988; Averill et al., 1994; Du et al., 2013; Fontes et al., 1994; Hirooka et al., 1997; Li et al., 2013, 2012; Oliveira et al., 2013; Potts et al., 2000; Silva et al., 1993; Zhou et al., 2010). While Ang II effects are mediated by its type $1\left(\mathrm{AT}_{1}\right)$

\footnotetext{
* Corresponding author at: Departamento de Ciências Fisiológicas, Instituto de Ciências Biológicas, Universidade Federal de Goiás, Goiânia, GO 74690-900, Brazil.

E-mail address: patferri@hotmail.com (P.M. Ferreira).
}

receptor (Averill et al., 1994; Hirooka et al., 1997), the G proteincoupled MAS receptor, mediates those evoked by Ang-(1-7) (Santos et al., 2003).

Spontaneously hypertensive rats (SHR) are a well-known model, widely used to investigate the contribution of brain RAS to the development and maintenance of primary hypertension. Several studies showed changes in the activity and in the levels of RAS components of SHR brains (Hirooka et al., 1997; Ito et al., 2000; Nakagaki et al., 2011; Phillips and de Oliveira, 2008). Increases in central angiotensinogen expression precede the development of hypertension in SHR (Tamura, 1996). These animals also show increases in the diencephalic angiotensinogen levels, likely evident from the fourth week of life (Shibata et al., 1993). In addition, renin-like activity in the anterior hypothalamus and in the nucleus tract solitarii (nTS) is higher during the development of hypertension in SHR, when compared to its control, Wistar rats (WT) (Ruiz et al., 1990). Ang II content as well as its turnover within the hypothalamus, and Ang II immunoreactivity within the paraventricular hypothalamus (PVN) and within the supraoptic nucleus (SFO) are substantially increased in adult SHR when compared to WT (Ganten et al., 1983; Phillips and Kimura, 1986; Weyhenmeyer and Phillips, 1982). SHR also exhibit increased density of Ang II binding sites within the median preoptic nucleus (MnPO), SFO, PVN and nTS, 
and AT1 receptor mRNA within the preoptic area (Gutkind et al., 1988; Komatus et al., 1996). Furthermore, it was demonstrated that the RVLM of SHR show an increase in the ACE and $\mathrm{AT}_{1}$ receptor density, besides showing greater pressor responses to intracerebroventricular (i.c.v.) injection of Ang II and by nanoinjections of Ang II into the preoptic area, nTS, RVLM and caudal ventrolateral medulla (CVLM) (Agarwal et al., 2011; Du et al., 2013; Matsuda et al., 1987; Muratani et al., 1991; Nakagaki et al., 2011; Phillips and de Oliveira, 2008; Wright et al., 1987; Zhu et al., 1998). More recently, Agarwal et al. demonstrated that levels of $\mathrm{ACE}_{2}$ and Mas receptor in the PVN and RVLM are reduced in SHR (Agarwal et al., 2011). Besides the involvement of central RAS in the pathophysiology of hypertension, Biancardi and colleagues suggested that changes in peripheral levels of Ang II modify the central permeability, which would facilitate its access to brain regions strongly involved in the control of blood pressure (Biancardi et al., 2014).

Although blood flow assessments show that different vascular beds are involved in arterial pressure changes evoked from both CVLM (Ferreira et al., 2008) and RVLM (Dampney, 1994; Dampney and McAllen, 1988; de Paula and Machado, 2001; Dean et al., 1992; Lovick, 1987; Willette et al., 1987), the question that still remains open is which peripheral vascular bed would be controlled by Ang II and Ang(1-7) signaling in the RVLM. Since RVLM and the peptides of RAS are important players in cardiovascular regulation, the present study shall evaluate whether nanoinjections of Ang-(1-7) and Ang II into the RVLM are able to alter regional blood flow in hypertensive rats.

\section{Materials and methods}

\subsection{General procedures}

\subsubsection{Surgeries}

Experiments were performed in adult male Wistar and spontaneously hypertensive rats (260-300 g). All experiments conformed to the regulation set forth by the Institutional Animal Welfare Committee (CETEA, UFMG), which are in accordance with the National Institutes of Health (NIH) Guidelines for the Care and Use of Laboratory Animals (NIH publication 80-23, revised in 1996). After anesthesia with urethane ( $1.2 \mathrm{~g} / \mathrm{kg}$ i.p., Sigma Chemical Co) animals were submitted to surgical procedures as described previously (Ferreira et al., 2008). Briefly, all the animals underwent tracheotomy and catheterization of femoral artery for arterial pressure measurement. Afterwards, animals were placed in a stereotaxic head holder (David Kopf instruments, CA) with the tooth bar $-11 \mathrm{~mm}$ below the level of the interaural line. The dorsal surface of the brainstem was exposed by a limited occipital craniotomy. A heating pad maintained a constant body temperature $\left(35-37^{\circ} \mathrm{C}\right)$.

\subsubsection{Injections into RVLM}

Injections into the RVLM were performed with a thin tip glass micropipette as previously described (Alzamora et al., 2006; Ferreira et al., 2008). Unilateral injections of Ang-(1-7) (40 ng; Bachem), Ang II (40 ng; Bachem) or sterile saline (vehicle $-\mathrm{NaCl} 0.9 \%$ ) were made into the RVLM (2.1 mm anterior, $1.8 \mathrm{~mm}$ lateral to the obex, and just above pia mater in the ventral surface). For all experiments, only one site of the RVLM was tested per animal and peptides were injected in a random order.

Arterial pressure and heart rate changes produced by injections into RVLM were recorded continuously (MP150 - AcqKnowledge Software/ Biopac System). A minimum interval of 20 min was waited between the pipette positioning and first central injection. A period of 30 min was waited among injections into RVLM.

\subsubsection{Cardiac output measurements}

Cardiac output (CO) was measured by the thermodilution method using a CARDIOTHERM 500 apparatus (Columbus Instrument, Columbus, $\mathrm{OH}$ ). A thermistor (Fr1.5 microprobe, outer diameter of $0.64 \mathrm{~mm}$ ) was inserted into the aortic arch through the left carotid artery for blood temperature measurement in WT $(n=6)$ and SHR $(n=4)$. A polyethylene catheter (PE10) was placed into the right atrium via jugular vein for saline injection. CO was measured by rapidly injecting $0.1 \mathrm{ml}$ of cold saline $\left(18-20^{\circ} \mathrm{C}\right)$ with a pump (HAMILTON, Microlab 500 series) into the right atria as a thermal tracer indicator. Three to four thermodilution curves were generated (minimum of 10 min interval) in the control period to assure the reproducibility of the measurement. The $\mathrm{CO}$ values obtained $5 \mathrm{~min}$ before and at the peak of the response elicited by RVLM microinjections were used to express the baseline and peptide-evoked responses, respectively. Total peripheral resistance (TPR) was calculated from MAP and CO values (TPR $=\mathrm{MAP} / \mathrm{CO}$, $\mathrm{mm} \mathrm{Hg} \times \mathrm{ml}^{-1} \times \mathrm{min}^{-1}$ ).

\subsubsection{Blood flow measurements}

In different groups of WT and SHR, femoral ( $\mathrm{n}=10$ and 9), renal ( $n=6$ and 4 ) or mesenteric ( $n=6$ and 5 ) blood flow were determined according to the method of Welch and colleagues (Welch et al., 1995) using a transit-time blood flowmeter (model T206; Transonics, NY, USA). A midline laparotomy was performed and miniature ultrasonic transit-time flow probe ( 0.5 or $0.7 \mathrm{~mm} \mathrm{V-series)} \mathrm{was} \mathrm{carefully} \mathrm{placed}$ around the artery (mesenteric, renal or femoral). Blood flow was recorded in an acquisition system (MP150 - Acqknowledge Software/ Biopac System). After 20 min of stabilization period, injections into RVLM were performed as described above (see section - Injections into RVLM). Mean vascular resistance was calculated as the ratio between mean arterial pressure and mean blood flow $(\mathrm{mm} \mathrm{Hg} / \mathrm{ml} / \mathrm{min}$ ).

\subsection{Histological verification of injection sites}

At the end of the experiments, the animals were euthanized with an overdose of anesthetic and the brain stem was carefully removed and fixed in $10 \%$ phosphate-buffered formalin for histological examination. Serial coronal sections $(40-50 \mu \mathrm{m})$ of the medulla oblongata were performed and stained with neutral red. The atlas of Paxinos and Watson (Paxinos and Watson, 1986) was used as reference. Only experiments with injections confined to the ventral part of the paragigantocellular nucleus were used in this study.

\subsection{Analysis}

Values at the peak of the responses were considered for each nanoinjection. All values were expressed as means \pm SEM. Values obtained before and after injections into RVLM were evaluated by Student's t-test. Comparisons among different groups were made by one-way ANOVA followed by Newman-Keuls. Significance was set at $\mathrm{p}<0.05$.

\section{Results}

Tables 1 and 2 show the pre injection (baseline) values of cardiovascular parameters measured in normotensive (WT) and hypertensive (SHR) animals, respectively, used in current experiments.

\subsection{Injections of Ang II and (1-7) into RVLM change heart rate and blood pressure of normotensive and hypertensive rats}

Fig. 1 is an example of coronal sections depicting injection site into RVLM. Representative chart recordings (Fig. 2) show the typical responses caused by injections of vehicle, Ang II and Ang-(1-7) into RVLM. In this case, the traces are from an experiment with SHR, where the increases in MAP and BF evoked by injections of Ang II and Ang-(1-7) were greater. Injections of Ang-(1-7) and Ang II into the RVLM of SHR produced a higher pressor response when compared to those evoked by the same injections in WT ( $\triangle \mathrm{MAP}: 17 \pm 2$ vs. $12 \pm$ $1 \mathrm{~mm} \mathrm{Hg}$ and $\triangle$ MAP: $21 \pm 2$ vs. $13 \pm 1 \mathrm{~mm} \mathrm{Hg}$; $\mathrm{p}<0.05$, respectively). Injections of saline into RVLM of SHR and WT induced small and 
Table 1

Baseline values of mean arterial pressure (MAP, $\mathrm{mm} \mathrm{Hg}$ ), heart rate (HR, beats/min), mean blood flow (BF, $\mathrm{ml} / \mathrm{min}$ ) and vascular resistance (VR, $\mathrm{mm} \mathrm{Hg} / \mathrm{ml} / \mathrm{min}$ ) of Wistar rats submitted to microinjection into the RVLM.

\begin{tabular}{lrllll}
\hline & $\mathrm{n}$ & \multicolumn{2}{l}{ Baseline values } & \\
\cline { 3 - 6 } & & $\begin{array}{l}\text { MAP } \\
(\mathrm{mm} \mathrm{Hg})\end{array}$ & $\begin{array}{l}\mathrm{HR} \\
(\text { beats/min })\end{array}$ & $\begin{array}{l}\mathrm{BF} \\
(\mathrm{ml} / \mathrm{min})\end{array}$ & $\begin{array}{l}\mathrm{VR} \\
(\mathrm{mm} \mathrm{Hg} / \mathrm{ml} / \mathrm{min})\end{array}$ \\
\hline $\begin{array}{l}\text { Saline } \\
\text { Femoral artery }\end{array}$ & 7 & $86 \pm 4$ & $329 \pm 19$ & $1.3 \pm 0.2$ & $72 \pm 9$ \\
Renal artery & 4 & $78 \pm 11$ & $333 \pm 22$ & $2.6 \pm 0.4$ & $33 \pm 9$ \\
Mesenteric artery & 5 & $65 \pm 3$ & $356 \pm 15$ & $3.4 \pm 0.6$ & $21 \pm 3$ \\
Ang-(1-7) & & & & & \\
Femoral artery & 10 & $85 \pm 5$ & $335 \pm 15$ & $1.5 \pm 0.2$ & $62 \pm 6$ \\
Renal artery & 4 & $70 \pm 6$ & $322 \pm 19$ & $2.3 \pm 0.6$ & $33 \pm 4$ \\
Mesenteric artery & 6 & $67 \pm 3$ & $345 \pm 12$ & $3.5 \pm 0.6$ & $22 \pm 2$ \\
Ang II & & & & & \\
Femoral artery & 5 & $98 \pm 7$ & $313 \pm 32$ & $1.5 \pm 0.3$ & $73 \pm 12$ \\
Renal artery & 6 & $81 \pm 5$ & $321 \pm 14$ & $2.5 \pm 0.4$ & $36 \pm 6$ \\
Mesenteric artery & 6 & $65 \pm 2$ & $349 \pm 13$ & $3.3 \pm 0.3$ & $21 \pm 2$ \\
\hline
\end{tabular}

The values are expressed as means \pm SEM; $n=$ number of animals.

transient pressor effects (Fig. 2 - BP tracing). Although the pressor effect produced by both Ang II and Ang-(1-7) was accompanied by a bidirectional and transient chronotropy (Fig. 2 - HR tracing), there were no differences in HR responses between SHR and WT.

\subsection{Cardiac output responses caused by nanoinjections of Ang II and Ang-} (1-7) into RVLM of normotensive and hypertensive rats

Cardiac output was unaffected by injections of Ang-(1-7) and Ang II into RVLM of WT, even with the pressor effects likely caused by medullary injection of both angiotensins [Ang-(1-7): $111 \pm 7 \mathrm{ml} / \mathrm{min}$ vs $107 \pm 4 \mathrm{ml} / \mathrm{min}$; Ang II: $112 \pm 13 \mathrm{ml} / \mathrm{min}$ vs $104 \pm 9 \mathrm{ml} / \mathrm{min}]$. Conversely, there was an increase in TPR of WT [Ang-(1-7): $0.75 \pm$ $0.07 \mathrm{~mm} \mathrm{Hg} / \mathrm{ml} / \mathrm{min}$ vs $0.69 \pm 0.08 \mathrm{~mm} \mathrm{Hg} / \mathrm{ml} / \mathrm{min}, \mathrm{p}<0.05$; Ang II: $0.79 \pm 0.05 \mathrm{~mm} \mathrm{Hg} / \mathrm{ml} / \mathrm{min}$ vs $0.67 \pm 0.06 \mathrm{~mm} \mathrm{Hg} / \mathrm{ml} / \mathrm{min}, \mathrm{p}<0.05$ (Fig. 3)]. Similarly, pressor effect of the peptides was not accompanied by CO responses in SHR [Ang-(1-7):120 $\pm 14 \mathrm{ml} / \mathrm{min}$ vs $130 \pm$ $10 \mathrm{ml} / \mathrm{min}$; Ang II: $139 \pm 12 \mathrm{ml} / \mathrm{min}$ vs $143 \pm 13 \mathrm{ml} / \mathrm{min}$ ] whereas TPR was increased [Ang-(1-7): $0.95 \pm 0.1 \mathrm{~mm} \mathrm{Hg} / \mathrm{ml} / \mathrm{min}$ vs $0.77 \pm$ $0.1 \mathrm{~mm} \mathrm{Hg} / \mathrm{ml} / \mathrm{min}, \mathrm{p}<0.05$; Ang II: $0.95 \pm 0.1 \mathrm{~mm} \mathrm{Hg} / \mathrm{ml} / \mathrm{min}$ vs $0.81 \pm 0.1 \mathrm{~mm} \mathrm{Hg} / \mathrm{ml} / \mathrm{min}, \mathrm{p}<0.05$; Fig. 3).

Table 2

Baseline values of mean arterial pressure (MAP, $\mathrm{mm} \mathrm{Hg}$ ), heart rate (HR, beats/min), mean blood flow (BF, $\mathrm{ml} / \mathrm{min}$ ) and vascular resistance (VR, $\mathrm{mm} \mathrm{Hg} / \mathrm{ml} / \mathrm{min}$ ) of SHR submitted to microinjection into the RVLM.

\begin{tabular}{|c|c|c|c|c|c|}
\hline & \multirow[t]{2}{*}{$\mathrm{n}$} & \multicolumn{4}{|c|}{ Baseline values } \\
\hline & & $\begin{array}{l}\text { MAP } \\
(\mathrm{mm} \mathrm{Hg})\end{array}$ & $\begin{array}{l}\mathrm{HR} \\
\text { (beats/min) }\end{array}$ & $\begin{array}{l}\mathrm{BF} \\
(\mathrm{ml} / \mathrm{min})\end{array}$ & $\begin{array}{l}\text { VR } \\
(\mathrm{mm} \mathrm{Hg} / \mathrm{ml} / \mathrm{min})\end{array}$ \\
\hline \multicolumn{6}{|l|}{ Saline } \\
\hline Femoral artery & 4 & $108 \pm 15$ & $294 \pm 22$ & $1.2 \pm 0.5$ & $120 \pm 32$ \\
\hline Renal artery & 4 & $100 \pm 7$ & $343 \pm 26$ & $2.1 \pm 0.4$ & $58 \pm 16$ \\
\hline Mesenteric artery & 5 & $81 \pm 6$ & $338 \pm 21$ & $3.2 \pm 0.4$ & $27 \pm 3$ \\
\hline \multicolumn{6}{|l|}{ Ang-(1-7) } \\
\hline Femoral artery & 8 & $109 \pm 7$ & $303 \pm 12$ & $1.3 \pm 0.3$ & $107 \pm 19$ \\
\hline Renal artery & 4 & $105 \pm 8$ & $346 \pm 18$ & $2.4 \pm 0.3$ & $49 \pm 12$ \\
\hline Mesenteric artery & 5 & $82 \pm 7$ & $338 \pm 22$ & $3.1 \pm 0.2$ & $27 \pm 2$ \\
\hline \multicolumn{6}{|l|}{ Ang II } \\
\hline Femoral artery & 9 & $103 \pm 4$ & $302 \pm 11$ & $1.3 \pm 0.2$ & $102 \pm 17$ \\
\hline Renal artery & 4 & $111 \pm 8$ & $336 \pm 13$ & $2.5 \pm 0.3$ & $49 \pm 10$ \\
\hline Mesenteric artery & 5 & $77 \pm 7$ & $340 \pm 22$ & $3.2 \pm 0.4$ & $25 \pm 4$ \\
\hline
\end{tabular}

The values are expressed as means $\pm \mathrm{SEM} ; \mathrm{n}=$ number of animals.

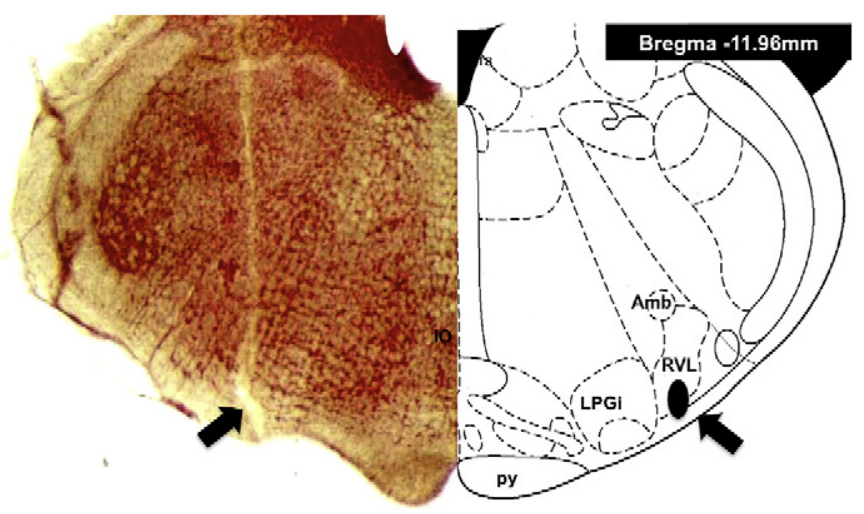

Fig. 1. Histological section of the medulla (left side) and a diagrammatic representation (right side) showing the center of the injections into RVLM (black arrows). Adapted from the atlas of Paxinos and Watson (Paxinos G. and Watson, C., 1986). Amb, ambiguus nucleus; py, pyramidal tractus; LPGi, lateral paragigantocellular nucleus.

3.3. Changes in vascular conductance in mesenteric, renal and femoral beds caused by nanoinjections of Ang II and Ang-(1-7) into RVLM of normotensive and hypertensive rats

The pressor effect evoked by Ang-(1-7) into RVLM of normotensive rats did not significantly alter blood flow in mesenteric or renal arteries. However, there was a significant increase in the femoral blood flow $(\Delta \mathrm{BF}=0.24 \pm 0.10 \mathrm{ml} / \mathrm{min}$ vs. $0.05 \pm 0.04 \mathrm{ml} / \mathrm{min}$, after saline $)$. Vascular resistance (VR) was unchanged in vascular beds studied: femoral $(\Delta \mathrm{VR}=0.11 \pm 1 \mathrm{~mm} \mathrm{Hg} / \mathrm{ml} / \mathrm{min}$ vs. $2.5 \pm 3.4 \mathrm{~mm} \mathrm{Hg} / \mathrm{ml} / \mathrm{min}$, after saline; $\Delta$ VR/VRbaseline $=-0.004 \pm 0.02$ vs. $0.01 \pm 0.03$, after saline); renal $(\Delta \mathrm{VR}=-3.7 \pm 5 \mathrm{~mm} \mathrm{Hg} / \mathrm{ml} / \mathrm{min}$ vs. $1.3 \pm 0.6 \mathrm{~mm} \mathrm{Hg} / \mathrm{ml} / \mathrm{min}$, after saline or $\Delta \mathrm{VR} / \mathrm{VRb}$ aseline $=-0.08 \pm 0.12 \mathrm{vs} .0 .04 \pm 0.01$, after saline $)$ and mesenteric $(\Delta \mathrm{VR}=1.2 \pm 0.7 \mathrm{~mm} \mathrm{Hg} / \mathrm{ml} / \mathrm{min}$ vs. $0.2 \pm$ $1 \mathrm{~mm} \mathrm{Hg} / \mathrm{ml} / \mathrm{min}$, after saline or $\Delta$ VR/VRbaseline $=0.04 \pm 0.04 \mathrm{vs}$. $-0.01 \pm 0.06$, after saline).

Differently, injection of Ang II into the RVLM of normotensive rats caused significant increases in the renal artery blood flow $(\triangle \mathrm{BF}=$ $0.20 \pm 0.04 \mathrm{ml} / \mathrm{min}$ vs. $0.02 \pm 0.03 \mathrm{ml} / \mathrm{min}$, after saline) but did not change femoral $(\triangle \mathrm{BF}=0.10 \pm 0.10 \mathrm{ml} / \mathrm{min}$ vs. $0.05 \pm 0.04 \mathrm{ml} / \mathrm{min}$, after saline) or mesenteric $(\Delta \mathrm{BF}=0.60 \pm 0.2 \mathrm{ml} / \mathrm{min}$ vs. $0.05 \pm$ $0.04 \mathrm{ml} / \mathrm{min}$, after saline) artery blood flow. Similar to Ang-(1-7), Ang II into the RVLM did not significantly alter vascular resistance in any vascular beds studied: femoral $(\Delta \mathrm{VR}=6 \pm 4.5 \mathrm{~mm} \mathrm{Hg} / \mathrm{ml} / \mathrm{min}$ vs. $2.5 \pm 3.4 \mathrm{~mm} \mathrm{Hg} / \mathrm{ml} / \mathrm{min}$, after saline; $\Delta$ VR/VRbaseline $=0.06 \pm$ 0.05 vs. $0.01 \pm 0.03$, after saline $)$; renal $(\Delta V R=3 \pm 0.7 \mathrm{~mm}$ $\mathrm{Hg} / \mathrm{ml} / \mathrm{min}$ vs. $1.3 \pm 0.6 \mathrm{~mm} \mathrm{Hg} / \mathrm{ml} / \mathrm{min}$, after saline or $\Delta$ VR $/$ VRbaseline $=$ $0.1 \pm 0.03$ vs. $0.04 \pm 0.01$, after saline $)$ or mesenteric $(\Delta \mathrm{VR}=1.4 \pm$ $1.0 \mathrm{~mm} \mathrm{Hg} / \mathrm{ml} / \mathrm{min}$ vs. $0.2 \pm 1 \mathrm{~mm} \mathrm{Hg} / \mathrm{ml} / \mathrm{min}$, after saline or $\Delta V R /$ RVbaseline $=0.06 \pm 0.05$ vs. $-0.01 \pm 0.06$, after saline)

As shown in Fig. 4, the pressor effect of Ang-(1-7) in the RVLM of SHR was due to increase in the vascular resistance of the renal and the mesenteric arteries. No alteration in the resistance of the femoral artery was observed. In addition, there were decreases in renal blood flow $(\Delta \mathrm{BF}=-0.2 \pm 0.06 \mathrm{ml} / \mathrm{min}$ vs. $0.01 \pm 0.01 \mathrm{ml} / \mathrm{min}$, saline; Fig. 4$)$ while blood flow in femoral or mesenteric arteries was unchanged.

Similar to Ang-(1-7), the pressor effect produced by Ang II in SHR was accompanied by increases in vascular resistance of the renal $(\Delta \mathrm{VR}=16 \pm 7 \mathrm{~mm} \mathrm{Hg} / \mathrm{ml} / \mathrm{min}$ vs. $0.9 \pm 0.7 \mathrm{~mm} \mathrm{Hg} / \mathrm{ml} / \mathrm{min}$, after saline or $\Delta V R / V R b a s e l i n e=0.3 \pm 0.07$ vs. $0.02 \pm 0.01$, after saline) and the mesenteric arteries $(\Delta \mathrm{VR}=7.8 \pm 0.7 \mathrm{~mm} \mathrm{Hg} / \mathrm{ml} / \mathrm{min}$ vs. $1.04 \pm$ $0.3 \mathrm{~mm} \mathrm{Hg} / \mathrm{ml} / \mathrm{min}$, saline or $\Delta$ VR/VRbaseline $=0.33 \pm 0.04$ vs. $0.05 \pm 0.02$, saline; Fig. 4), but resistance in femoral bed was not modified $(\Delta V R=5.1 \pm 3.7 \mathrm{~mm} \mathrm{Hg} / \mathrm{ml} / \mathrm{min}$ vs. $4.6 \pm 3.1 \mathrm{~mm} \mathrm{Hg} / \mathrm{ml} / \mathrm{min}$, after saline or $\Delta V R / V R b a s e l i n e=0.04 \pm 0.03$ vs. $0.02 \pm 0.03$, after saline). Ang II also produced significant decreases in renal blood flow 
A

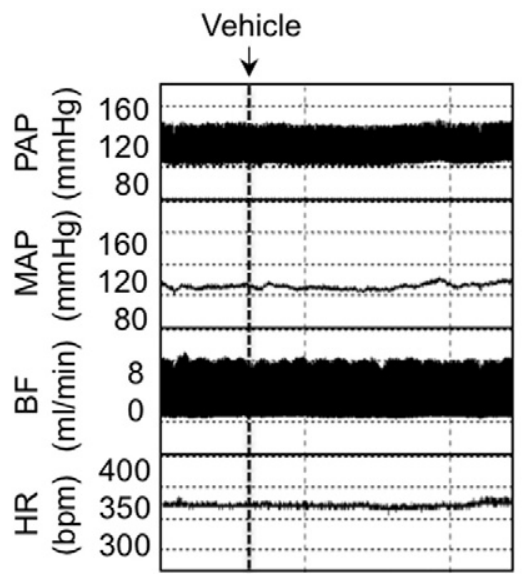

Ang II

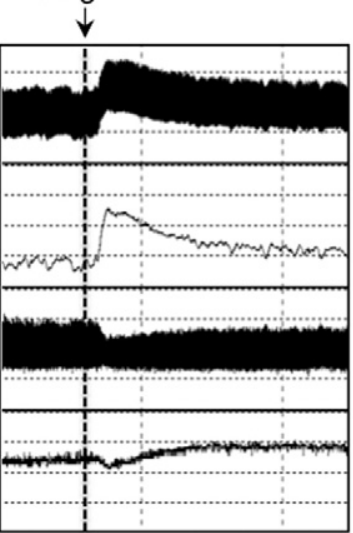

Ang-(1-7)

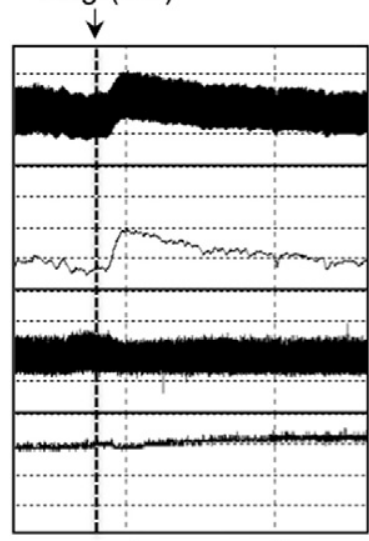

$2 \min$

B
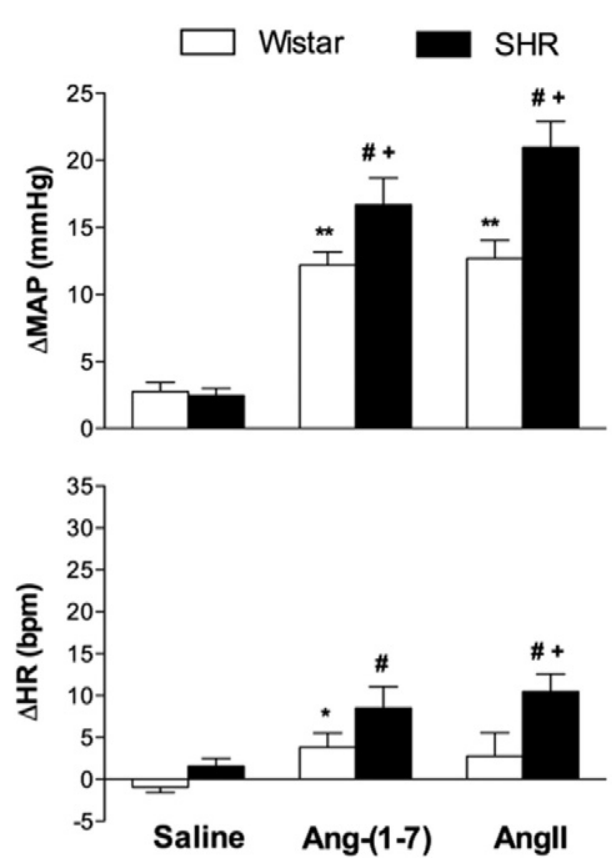

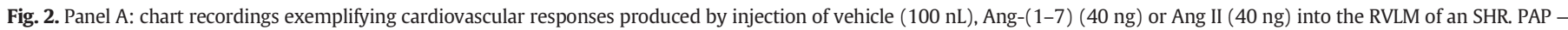

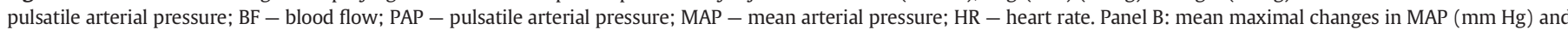

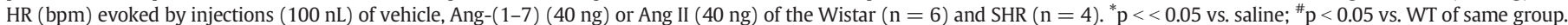
(ANOVA followed by Newman-Keuls).

$(\Delta \mathrm{BF}=-0.2 \pm 0.06 \mathrm{ml} / \mathrm{min}$ vs. $0.01 \pm 0.01 \mathrm{ml} / \mathrm{min}$, saline $)$, without altering femoral $(\triangle \mathrm{BF}=0.2 \pm 0.07 \mathrm{ml} / \mathrm{min} \mathrm{vs} .0 .04 \pm 0.06 \mathrm{ml} / \mathrm{min}$, saline) or mesenteric blood flow $(\Delta \mathrm{BF}=-0.1 \pm 0.08 \mathrm{ml} / \mathrm{min}$ vs. $-0.06 \pm$ $0.03 \mathrm{ml} / \mathrm{min}$, saline; Fig. 4). Therefore, in SHR, the hypertensive effect of both Ang II and Ang-(1-7) were accompanied by increase in the renal and mesenteric vascular resistance, and decrease in the renal blood flow.

\section{Discussion}

Our main findings were: i) in normotensive rats, Ang-(1-7) into RVLM increased femoral blood flow while Ang II increased renal blood flow, without changing vascular resistance of the beds studied; and ii) in hypertensive rats, both Ang-(1-7) and Ang II increased vascular resistance of renal and mesenteric beds, and reduced blood flow of renal artery. Altogether, these data indicate that angiotensinergic synapses in rostral ventrolateral medulla may exert differential control of vascular resistance and blood flow during hypertension.

Within plenty of experimental models, SHR are a widely used model of primary hypertension. SHR present significant increases in the sympathetic outflow, which affects vasomotion (Allen, 2002; Judy et al., 1976; Li et al., 2013, 2012; Lundin et al., 1984). Several studies suggest that the mechanisms involved in this excessive sympathoexcitation include increases in Ang II levels in the brain, which would change the activity of sympathetic supplies and cause vasoconstriction (Berecek et al., 1984; Falcon et al., 1978; Gyurko et al., 1993; Phillips, 1983; Phillips and Kimura, 1986; Wielbo et al., 1995). RVLM is one of the main sympathetic premotor areas that exhibit increases in neuronal excitability (Chan et al., 1991) and overexpression of $\mathrm{AT}_{1}$ receptors (Gehlert et al., 1991; Gutkind et al., 1988) in SHR. In this regard, the responses we found following injection of Ang II into RVLM of SHR are consistent with several previous studies (Chan et al., 1990, 1991; Ito et al., 2002; Seyedabadi et al., 2001; Zhu et al., 1998), with the exception of contrasting findings (Averill et al., 1994; Muratani et al., 1991, 1993; Tsuchihashi et al., 1999) likely attributed to differences in the methodology. Even so, these authors also observed potentiation of the depressor response produced by antagonism of $\mathrm{AT}_{1}$ in the RVLM of SHR (Averill et al., 1994; Ito et al., 2002; Muratani et al., 1993; Zhu et al., 1998).

Two plausible hypotheses may explain the increases in the responsiveness of RVLM of SHR to angiotensins: i) changes in neuronal activity 
Normotensive
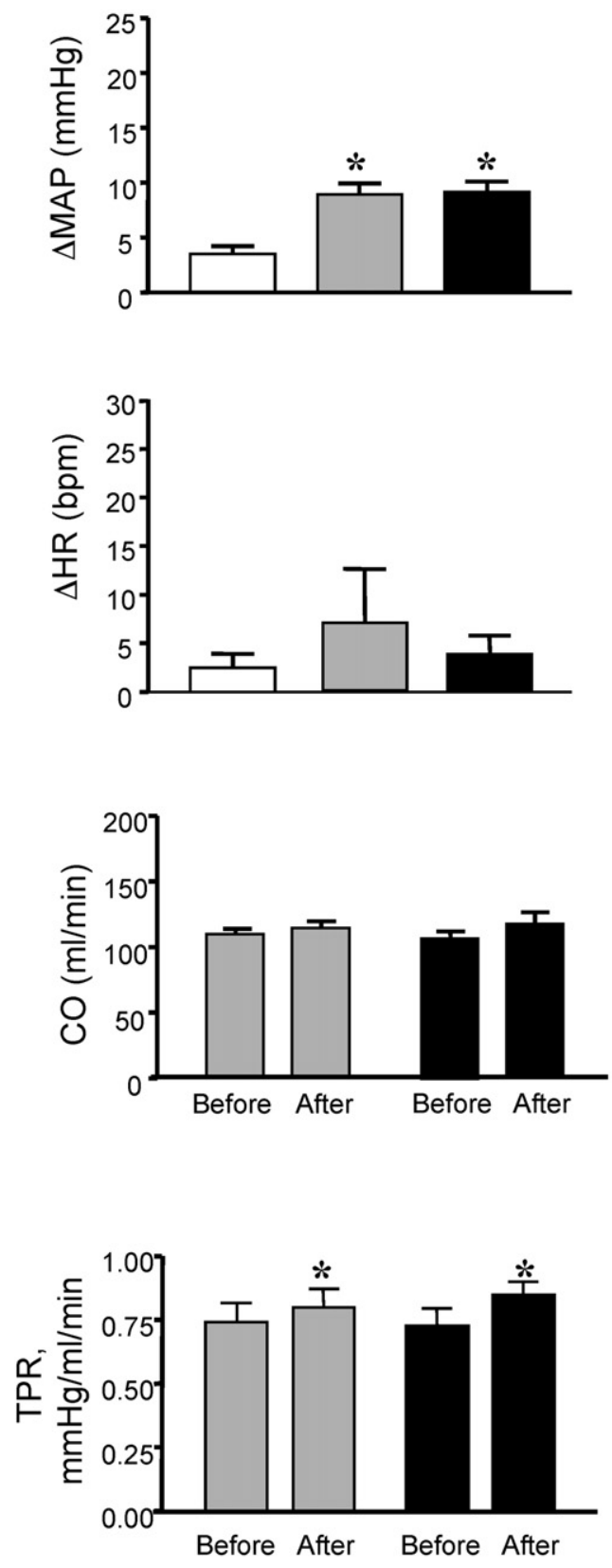

Hypertensive
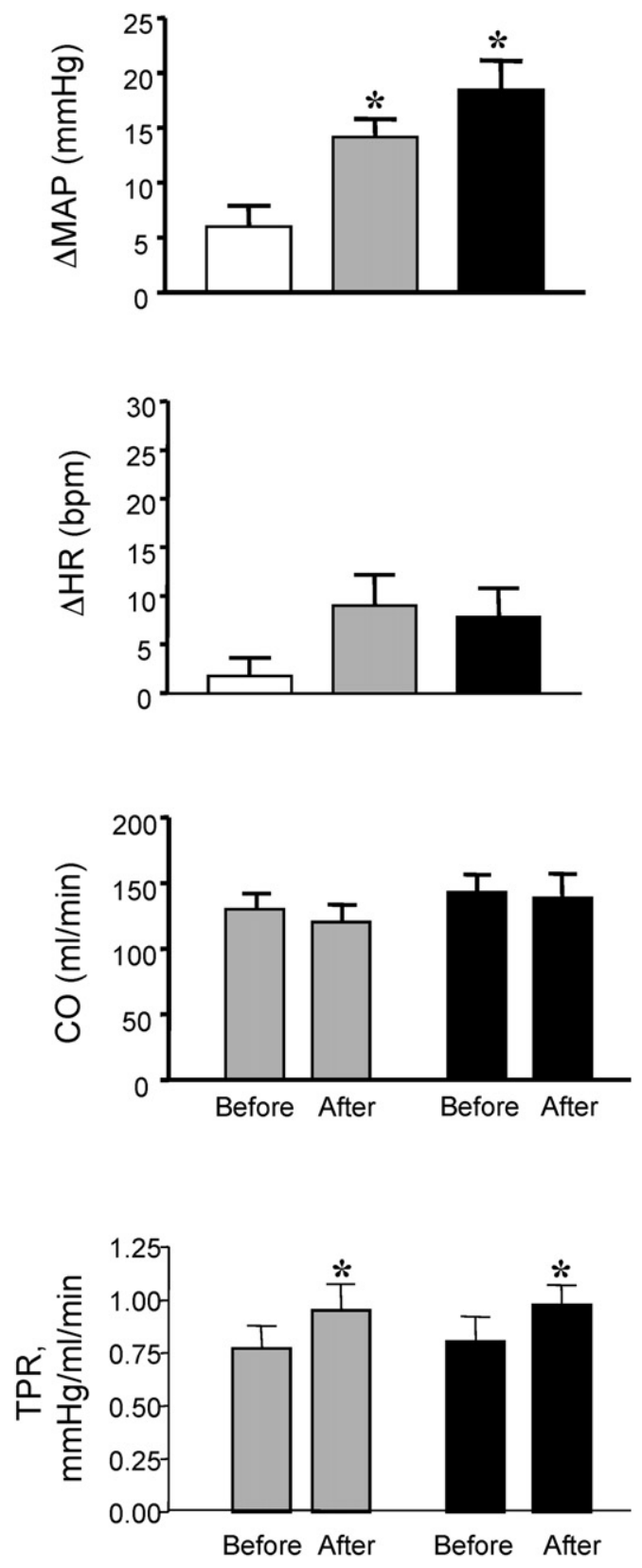

Saline

Ang-(1-7)

Ang II

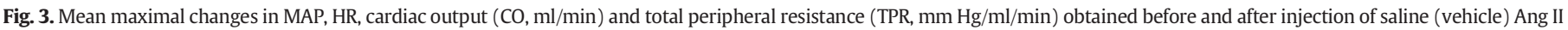

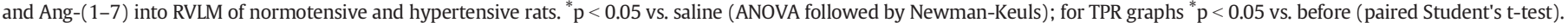

and excitability; and ii) increases in the density and/or affinity to angiotensin receptors. In fact, changes in firing rate of RVLM neurons seem to play a key role in the development and maintenance of hypertension (Chan et al., 1990, 1991; Ito et al., 2000; Kumagai et al., 2012; Kuo and Yang, 2000; Matsuura et al., 2002; Minson et al., 1996). These changes in the activity of RVLM neurons may be related to the modified responsivity to excitatory input (Ito et al., 2000; Lin et al., 1995; Tsuchihashi et al., 1994), besides the increases in the density of $\mathrm{AT}_{1}$ receptors in the RVLM of SHR (Gehlert et al., 1991; Gutkind et al., 1988; Hu et al., 2002). The activity of RVLM neurons may be modified by supramedullary sources of angiotensinergic inputs (Ganten et al.,
1983; Phillips and Sumners, 1998) and mediated by $\mathrm{AT}_{1}$ receptors, as suggested by Ito and colleagues (Ito et al., 2002). The presence of Ang II in nerve terminals (Lind et al., 1985) and binding sites with high affinity for Ang II in the RVLM provide further support to our hypotheses (Allen et al., 1988; Gehlert et al., 1991; Song et al., 1992; Speth and Kim, 1990).

Although the mechanisms involved in the differential neuronal properties of sympathetic premotor neurons during hypertension remain poorly understood, some studies reported on the origin of the angiotensinergic inputs to RVLM. Tagawa and Dampney (Tagawa and Dampney, 1999) showed that blockade of $\mathrm{AT}_{1}$ but not glutamate 
Femoral Bed
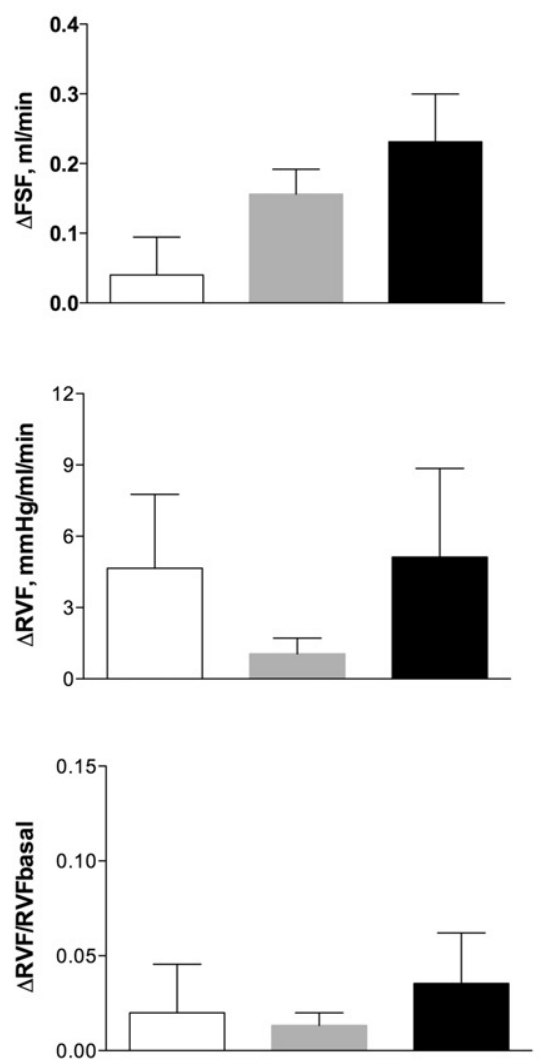

Renal Bed
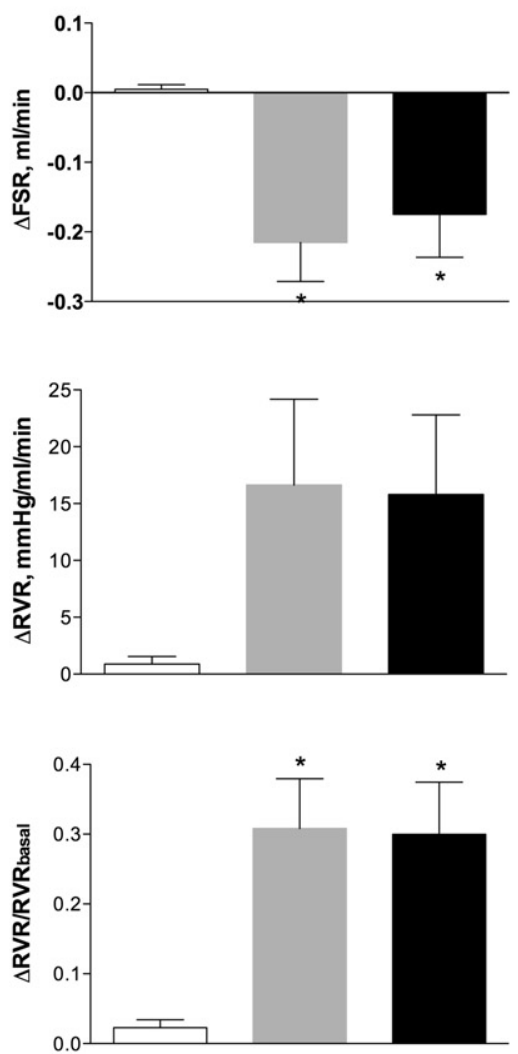

Mesenteric Bed
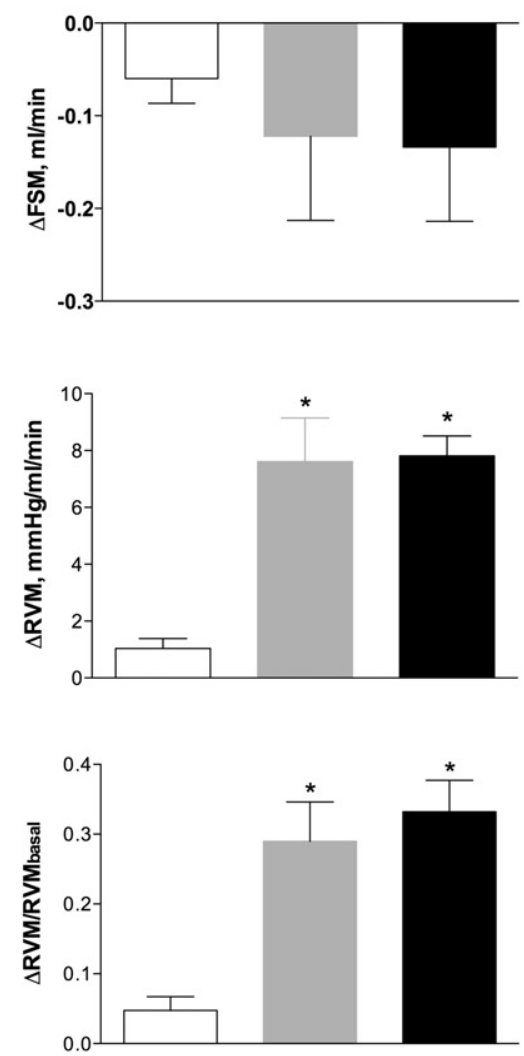

Saline

Ang-(1-7)

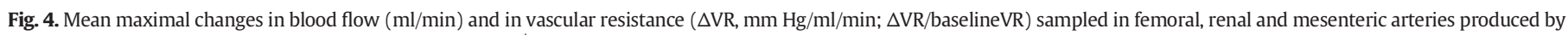
injections of saline, Ang-(1-7) and Ang II into RVLM of SHR. * $\mathrm{p}<0.05$ vs. saline (ANOVA followed by Newman-Keuls).

receptors in the RVLM attenuated the responses evoked from paraventricular hypothalamus (PVN). Ito and colleagues (Ito et al., 2002) showed that this PVN-RVLM angiotensinergic pathway is tonically active in $\mathrm{SHR}$, since the hypotension evoked by activation of $\mathrm{GABA}_{\mathrm{A}}$ receptors in the PVH depends on an $\mathrm{AT}_{1}$-mediated relay in RVLM. It is noteworthy that the hyperactive diencephalic neurons (Allen, 2002) may be the source of angiotensinergic output to RVLM during hypertension.

The present study pioneered in the field in showing that the Ang-(17 ) also acts differentially in medullary sympathetic premotor neurons of SHR. While the greater pressor responses produced by Ang II and Ang(1-7) in the RVLM of SHR were unrelated to changes in cardiac output, the pressor response caused by Ang-(1-7) is increased in SHR. The literature states that Ang-(1-7) produces central effects similar to those evoked by Ang II (Campagnole-Santos et al., 1989, 1990, 1992; Diz and Pirro, 1992; Du et al., 2013; Li et al., 2012; Oliveira et al., 2013; Silva and Schreihofer, 2011; Zhou et al., 2010). The pressor responses evoked by Ang-(1-7) in rostral areas (Fontes et al., 1997; Potts et al., 2000) are opposite to those caused by the same injections in the caudal ventrolateral medulla (Alzamora et al., 2002; Ferreira et al., 2008; Potts et al., 2000; Silva et al., 1993).

To the best of our knowledge, there is no report on the modification of Ang-(1-7) binding sites in medullary areas of different experimental models of hypertension, whereas the literature provides robust evidences for Ang II-AT ${ }_{1}$ axis. Transgenic rats with low brain angiotensinogen display an increase in the density of $\mathrm{AT}_{1}$ receptors at different brain areas - including VLM (Monti et al., 2001) - and augmented pressor responses to injections of Ang II or Ang-(1-7) into RVLM (Baltatu et al., 2001), which is in agreement with current findings. These evidences suggest simultaneous changes in $\mathrm{AT}_{1}$ and Mas (or other) receptors in the RVLM. Although the cardiovascular effects triggered by Ang II and Ang-(1-7) in the VLM are similar (Fontes et al., 1997; Potts et al., 2000), mechanisms can be differential in the VLM (Alzamora et al., 2002; Oliveira et al., 2013). While the pressor effect evoked from Ang II prominently results from a sympathetically-mediated increase in vasomotion (Dampney, 1994; Muratani et al., 1991), those evoked by Ang-(1-7) may result from a sympathetic activation, vasopressin release and inhibition of cholinergicsensitive beds (Oliveira et al., 2013). Furthermore, consistent evidences show that $\mathrm{AT}_{1}$ and Mas receptors are the mediators of Ang II and Ang(1-7) evoked responses, respectively. Furthermore, consistent evidences show that $\mathrm{AT}_{1}$ and Mas receptors are the mediators of Ang II and Ang-(17) evoked responses, respectively (Du et al., 2013; Li et al., 2012; Nakagaki et al., 2011; Zhou et al., 2010).

SHR exhibit increases in immunoreactivity to $\mathrm{AT}_{1}$ receptors in glutamatergic and GABAergic RVLM neurons expressing tyrosine hydroxylase (Hu et al., 2002). These results suggest that Ang II may be putative in the balance between excitatory and inhibitory inputs controlling the activity of RVLM neurons (Averill et al., 1994; Fontes et al., 1997, 1994; Hirooka et al., 1997).We confirmed that changes in central RAS indeed modify the amplitude of cardiovascular responses to blockade and to stimulation of $\mathrm{GABA}_{\mathrm{A}}$ hypothalamic receptors (da Silva et al., 2011). Interestingly, the antagonism of AT1 receptor in rat strains with hyperactive RAS (SHR, TGR (mREN2)27, Dahl-salt) causes hypotension (Fontes et al., 2000; Ito et al., 2003, 2002) whereas no change in blood pressure is found in transgenic mice where synthesis of brain 
angiotensinogen is inhibited (Baltatu et al., 2001). Jointly, these data suggest that the modulatory role of Ang II on the peripheral sympathetic activity results from the balance between excitation and inhibition.

Despite the absence of data on the distribution of Ang-(1-7) receptors in different neurons of RVLM, it is possible that SHR show differential activity of glutamatergic and GABAergic neurons and/or non-uniform distribution of angiotensin receptors in these neurons, which may facilitate sympathoexcitation. Cardiac control might be similarly affected, since the changes in the balance between excitatory/inhibitory inputs produced by angiotensins in the RVLM result in pressor responses that are accompanied by variable chronotropy. Baroreflex influences should be considered, despite the responses to injections into RVLM seem to oppose the baroreflex patterns. Our results support this idea as the pressor responses produced by angiotensins in the RVLM of SHR were accompanied by significant tachycardia. However, we cannot neglect that possible differences in the baroreflex responsiveness and in the RVLM between Wistar and SHR rats may modify the function of pathways innervating the heart. Since sympathetic outflow to different organs can be governed independently, changes in the cardiovascular control may result in different patterns of responses in the heart and different vascular beds, in order to set specific adjustments in the perfusion and cardiac function (Dampney et al., 2002).

The RVLM contains sub-populations of neurons that change the activity of specific vascular territories (Dean et al., 1992; Lovick, 1987; McAllen and Dampney, 1990). Substantial evidences suggest a topographic distribution in the RVLM premotor neurons controlling different vascular regions (Dampney, 1994; Dampney and McAllen, 1988; Dean et al., 1992; Lovick, 1987; McAllen and Dampney, 1990; McAllen and May, 1994; Willette et al., 1987). In spite of the probable overlap, Dampney and McAllen (Dampney and McAllen, 1988) observed that the increased activity of sympathetic supplies innervating skin and skeletal muscles are predominantly evoked from medial and lateral aspects of RVLM, respectively. On the other hand, mapping studies accomplished by De Paula and Machado (de Paula and Machado, 2001) observed pressor responses accompanied by equipotent increases in the vascular resistance of renal, mesenteric and hind limb beds, which suggest a lack of topographical organization with respect to these territories. We hypothesize that the different patterns of responses among vascular beds of SHR may be attributed to a differential control of regional sympathetic supplies. However, it is important to emphasize that other regional, vascular and autonomic mechanisms may be involved in differential responses observed in SHR (Kumagai et al., 2012; Safar et al., 2001).

In normotensive rats, the pressor responses produced by Ang-(1-7) or Ang II into RVLM were not accompanied by changes in vascular resistance of territories studied (femoral, renal or mesenteric), while a significant increase in femoral and in renal blood flows were found after injection of Ang-(1-7) and Ang II respectively. These suggest that these peptides in the RVLM may change the resistance of othervascular bed(s) and the pressor responses result from small changes in different territories. Our data, obtained from unilateral injections into RVLM, does not indicate differences between the two peptides, as observed for bilateral approaches in the CVLM (Ferreira et al., 2008). There is no doubt, however, that pressor responses produced by angiotensins in the RVLM are largely dependent on adjustments in peripheral vascular resistance, since these responses were not accompanied by significant changes in cardiac output. In conclusion, Ang-(1-7) and Ang II seem to govern the changes in vascular resistance of renal and mesenteric beds, besides reducing blood flow of renal artery during essential hypertension. Whether or not the influence of these peptides in different brain areas plays a role in the pathophysiology of hypertension remains to be unraveled.

\section{Acknowledgments}

This study was supported by PRONEX (Programa de Núcleos de Excelência from FAPEMIG -Fundação de Amparo à Pesquisa do Estado de Minas Gerais and CNPq -Conselho Nacional de Desenvolvimento Científico e Tecnológico (Proc\# CBB-APQ-04758-10)). PM Ferreira was a recipient of CAPES-PICDT fellowship (Doctoral Degree) from the Federal University of Goiás. We are thankful to Jose R. Silva for skillful technical assistance.

\section{References}

Agarwal, D., Welsch, M.A., Keller, J.N., Francis, J., 2011. Chronic exercise modulates RAS components and improves balance between pro- and anti-inflammatory cytokines in the brain of SHR. Basic Res. Cardiol. 106, 1069-1085.

Allen, A.M., 2002. Inhibition of the hypothalamic paraventricular nucleus in spontaneously hypertensive rats dramatically reduces sympathetic vasomotor tone. Hypertension 39, 275-280.

Allen, A.M., Dampney, R.A., Mendelsohn, F.A., 1988. Angiotensin receptor binding and pressor effects in cat subretrofacial nucleus. Am. J. Phys. 255, H1011-H1017.

Alzamora, A.C., Santos, R.A., Campagnole-Santos, M.J., 2002. Hypotensive effect of ANG II and ANG-(1-7) at the caudal ventrolateral medulla involves different mechanisms. Am. J. Physiol. Regul. Integr. Comp. Physiol. 283, R1187-R1195.

Alzamora, A.C., Santos, R.A., Campagnole-Santos, M.J., 2006. Baroreflex modulation by angiotensins at the rat rostral and caudal ventrolateral medulla. Am. J. Physiol. Regul. Integr. Comp. Physiol. 290, R1027-R1034.

Andreatta, S.H., Averill, D.B., Santos, R.A., Ferrario, C.M., 1988. The ventrolateral medulla. A new site of action of the renin-angiotensin system. Hypertension 11, I163-I166.

Averill, D.B., Tsuchihashi, T., Khosla, M.C., Ferrario, C.M., 1994. Losartan, nonpeptide angiotensin II-type 1 (AT1) receptor antagonist, attenuates pressor and sympathoexcitatory responses evoked by angiotensin II and L-glutamate in rostral ventrolateral medulla. Brain Res. 665, 245-252.

Baltatu, O., Fontes, M.A., Campagnole-Santos, M.J., Caligiorni, S., Ganten, D., Santos, R.A., Bader, M., 2001. Alterations of the renin-angiotensin system at the RVLM of transgenic rats with low brain angiotensinogen. Am. J. Physiol. Regul. Integr. Comp. Physiol. 280, R428-R433.

Berecek, K.H., Nagahama, S., Oparil, S., 1984. Effect of central administration of MK-422 (the diacid form of enalapril) on the development of hypertension in the spontaneously hypertensive rat. J. Hypertens. Suppl. 2, S63-S66.

Biancardi, V.C., Son, S.J., Ahmadi, S., Filosa, J.A., Stern, J.E., 2014. Circulating angiotensin II gains access to the hypothalamus and brain stem during hypertension via breakdown of the blood-brain barrier. Hypertension 63, 572-579.

Campagnole-Santos, M.J., Diz, D.I., Ferrario, C.M., 1990. Actions of angiotensin peptides after partial denervation of the solitary tract nucleus. Hypertension 15, I34-I39.

Campagnole-Santos, M.J., Diz, D.I., Santos, R.A., Khosla, M.C., Brosnihan, K.B., Ferrario, C.M., 1989. Cardiovascular effects of angiotensin-(1-7) injected into the dorsal medulla of rats. Am. J. Phys. 257, H324-H329.

Campagnole-Santos, M.J., Heringer, S.B., Batista, E.N., Khosla, M.C., Santos, R.A., 1992. Differential baroreceptor reflex modulation by centrally infused angiotensin peptides. Am. J. Phys. 263, R89-R94.

Chan, R.K., Chan, Y.S., Wong, T.M., 1990. Cardiovascular responses to electrical stimulation of the ventrolateral medulla of the spontaneously hypertensive rat. Brain Res. 522, 99-106.

Chan, R.K., Chan, Y.S., Wong, T.M., 1991. Electrophysiological properties of neurons in the rostral ventrolateral medulla of normotensive and spontaneously hypertensive rats. Brain Res. 549, 118-126.

Dampney, R.A., 1994. Functional organization of central pathways regulating the cardiovascular system. Physiol. Rev. 74, 323-364.

Dampney, R.A., McAllen, R.M., 1988. Differential control of sympathetic fibres supplying hindlimb skin and muscle by subretrofacial neurones in the cat. J. Physiol. 395, 41-56.

Dampney, R.A., Coleman, M.J., Fontes, M.A., Hirooka, Y., Horiuchi, J., Li, Y.W., Polson, J.W., Potts, P.D., Tagawa, T., 2002. Central mechanisms underlying short- and long-term regulation of the cardiovascular system. Clin. Exp. Pharmacol. Physiol. 29, 261-268.

Dean, C., Seagard, J.L., Hopp, F.A., Kampine, J.P., 1992. Differential control of sympathetic activity to kidney and skeletal muscle by ventral medullary neurons. J. Auton. Nerv. Syst. 37, 1-10.

Diz, D.I., Pirro, N.T., 1992. Differential actions of angiotensin II and angiotensin-(1-7) on transmitter release. Hypertension 19, II41-II48.

Du, D., Chen, J., Liu, M., Zhu, M., Jing, H., Fang, J., Shen, L., Zhu, D., Yu, J., Wang, J., 2013. The effects of angiotensin II and angiotensin-(1-7) in the rostral ventrolateral medulla of rats on stress-induced hypertension. PLoS One 8, e70976.

Falcon II, J.C., Phillips, M.I., Hoffman, W.E., Brody, M.J., 1978. Effects of intraventricular angiotensin II mediated by the sympathetic nervous system. Am. J. Phys. 235, H392-H399.

Ferreira, P.M., Alzamora, A.C., Santos, R.A., Campagnole-Santos, M.J., 2008. Hemodynamic effect produced by microinjection of angiotensins at the caudal ventrolateral medulla of spontaneously hypertensive rats. Neuroscience 151, 1208-1216.

Fontes, M.A., Baltatu, O., Caligiorne, S.M., Campagnole-Santos, M.J., Ganten, D., Bader, M., Santos, R.A., 2000. Angiotensin peptides acting at rostral ventrolateral medulla contribute to hypertension of TGR(mREN2)27 rats. Physiol. Genomics 2, 137-142.

Fontes, M.A., Martins Pinge, M.C., Naves, V. Campagnole-Santos, M.J. Lopes, O.U. Khosla M.C., Santos, R.A., 1997. Cardiovascular effects produced by microinjection of angiotensins and angiotensin antagonists into the ventrolateral medulla of freely moving rats. Brain Res. 750, 305-310.

Fontes, M.A., Silva, L.C., Campagnole-Santos, M.J., Khosla, M.C., Guertzenstein, P.G., Santos, R.A., 1994. Evidence that angiotensin-(1-7) plays a role in the central control of blood pressure at the ventro-lateral medulla acting through specific receptors. Brain Res. $665,175-180$. 
Ganten, D., Hermann, K., Bayer, C., Unger, T., Lang, R.E., 1983. Angiotensin synthesis in the brain and increased turnover in hypertensive rats. Science 221, 869-871.

Gehlert, D.R., Gackenheimer, S.L., Schober, D.A., 1991. Autoradiographic localization of subtypes of angiotensin II antagonist binding in the rat brain. Neuroscience 44 , 501-514.

Gutkind, J.S., Kurihara, M., Castren, E., Saavedra, J.M., 1988. Increased concentration of angiotensin II binding sites in selected brain areas of spontaneously hypertensive rats. J. Hypertens. 6, 79-84.

Gyurko, R., Wielbo, D., Phillips, M.I., 1993. Antisense inhibition of AT1 receptor mRNA and angiotensinogen mRNA in the brain of spontaneously hypertensive rats reduces hypertension of neurogenic origin. Regul. Pept. 49, 167-174.

Hirooka, Y., Potts, P.D., Dampney, R.A., 1997. Role of angiotensin II receptor subtypes in mediating the sympathoexcitatory effects of exogenous and endogenous angiotensin peptides in the rostral ventrolateral medulla of the rabbit. Brain Res. 772, 107-114.

Hu, L., Zhu, D.N., Yu, Z., Wang, J.Q., Sun, Z.J., Yao, T., 2002. Expression of angiotensin II type 1 (AT(1)) receptor in the rostral ventrolateral medulla in rats. J. Appl. Physiol. (1985) 92, 2153-2161.

Ito, S., Hiratsuka, M., Komatsu, K., Tsukamoto, K., Kanmatsuse, K., Sved, A.F., 2003. Ventrolateral medulla AT1 receptors support arterial pressure in Dahl saltsensitive rats. Hypertension 41, 744-750.

Ito, S., Komatsu, K., Tsukamoto, K., Kanmatsuse, K., Sved, A.F., 2002. Ventrolateral medulla AT1 receptors support blood pressure in hypertensive rats. Hypertension 40, 552-559.

Ito, S., Komatsu, K., Tsukamoto, K., Sved, A.F., 2000. Excitatory amino acids in the rostral ventrolateral medulla support blood pressure in spontaneously hypertensive rats. Hypertension 35, 413-417.

Judy, W.V., Watanabe, A.M., Henry, D.P., Besch Jr., H.R., Murphy, W.R., Hockel, G.M., 1976 Sympathetic nerve activity: role in regulation of blood pressure in the spontaenously hypertensive rat. Circ. Res. 38, 21-29.

Komatus, C., Shibata, K., Furukawa, T., 1996. The developmental increase of the AT1A, but not the AT1B, receptor mRNA level at the preoptic area in spontaneously hypertensive rats. Life Sci. 58, 1109-1121.

Kumagai, H., Oshima, N., Matsuura, T., Iigaya, K., Imai, M., Onimaru, H., Sakata, K., Osaka, M., Onami, T., Takimoto, C., Kamayachi, T., Itoh, H., Saruta, T., 2012. Importance of rostral ventrolateral medulla neurons in determining efferent sympathetic nerve activity and blood pressure. Hypertens. Res. 35, 132-141.

Kuo, T.B., Yang, C.C., 2000. Altered frequency characteristic of central vasomotor control in SHR. Am. J. Physiol. Heart Circ. Physiol. 278, H201-H207.

Li, P., Sun, H.J., Cui, B.P., Zhou, Y.B., Han, Y., 2013. Angiotensin-(1-7) in the rostral ventrolateral medulla modulates enhanced cardiac sympathetic afferent reflex and sympathetic activation in renovascular hypertensive rats. Hypertension 61, 820-827.

Li, P., Zhang, F., Zhou, Y.B., Cui, B.P., Han, Y., 2012. Superoxide anions modulate the effects of angiotensin-(1-7) in the rostral ventrolateral medulla on cardiac sympathetic afferent reflex and sympathetic activity in rats. Neuroscience 223, 388-398.

Lin, J.C., Tsao, W.L., Wang, Y., 1995. Cardiovascular effects of NMDA in the RVLM of spontaneously hypertensive rats. Brain Res. Bull. 37, 289-294.

Lind, R.W., Swanson, L.W., Ganten, D., 1985. Organization of angiotensin II immunoreactive cells and fibers in the rat central nervous system. An immunohistochemical study. Neuroendocrinology 40, 2-24.

Lovick, T.A., 1987. Differential control of cardiac and vasomotor activity by neurones in nucleus paragigantocellularis lateralis in the cat. J. Physiol. 389, 23-35.

Lundin, S., Ricksten, S.E., Thoren, P., 1984. Renal sympathetic activity in spontaneously hypertensive rats and normotensive controls, as studied by three different methods. Acta Physiol. Scand. 120, 265-272.

Matsuda, T., Shibata, K., Abe, M., Tomonaga, M., Furukawa, T., 1987. Potentiation of pressor response to angiotensin II at the preoptic area in spontaneously hypertensive rat. Life Sci. 41, 749-754

Matsuura, T., Kumagai, H., Kawai, A., Onimaru, H., Imai, M., Oshima, N., Sakata, K., Saruta, T., 2002. Rostral ventrolateral medulla neurons of neonatal Wistar-Kyoto and spontaneously hypertensive rats. Hypertension 40, 560-565.

McAllen, R.M., Dampney, R.A., 1990. Vasomotor neurons in the rostral ventrolateral medulla are organized topographically with respect to type of vascular bed but not body region. Neurosci. Lett. 110, 91-96.

McAllen, R.M., May, C.N., 1994. Differential drives from rostral ventrolateral medullary neurons to three identified sympathetic outflows. Am. J. Phys. 267, R935-R944.

Minson, J., Arnolda, L., Llewellyn-Smith, I., Pilowsky, P., Chalmers, J., 1996. Altered c-fos in rostral medulla and spinal cord of spontaneously hypertensive rats. Hypertension 27, 433-441.

Monti, J., Schinke, M., Bohm, M., Ganten, D., Bader, M., Bricca, G., 2001. Glial angiotensinogen regulates brain angiotensin II receptors in transgenic rats TGR(ASrAOGEN). Am. J. Physiol. Regul. Integr. Comp. Physiol. 280, R233-R240.

Muratani, H., Averill, D.B., Ferrario, C.M., 1991. Effect of angiotensin II in ventrolateral medulla of spontaneously hypertensive rats. Am. J. Phys. 260, R977-R984.

Muratani, H., Ferrario, C.M., Averill, D.B., 1993. Ventrolateral medulla in spontaneously hypertensive rats: role of angiotensin II. Am. J. Phys. 264, R388-R395.

Nakagaki, T., Hirooka, Y., Ito, K., Kishi, T., Hoka, S., Sunagawa, K., 2011. Role of angiotensin$(1-7)$ in rostral ventrolateral medulla in blood pressure regulation via sympathetic nerve activity in Wistar-Kyoto and spontaneous hypertensive rats. Clin. Exp. Hypertens. 33, 223-230.
Oliveira, R.C., Campagnole-Santos, M.J., Santos, R.A., 2013. The pressor effect of angiotensin-(1-7) in the rat rostral ventrolateral medulla involves multiple peripheral mechanisms. Clinics (Sao Paulo) 68, 245-252.

de Paula, P.M., Machado, B.H., 2001. Changes in regional vascular resistance in response to microinjection of L-glutamate into different antero-posterior coordinates of the RVLM in awake rats. Auton. Neurosci. 87, 301-309.

Paxinos, G., Watson, C., 1986. The Rat Brain in Stereotaxic Coordinates. Academic Press, New York.

Phillips, M.I., 1983. New evidence for brain angiotensin and for its role in hypertension. Fed. Proc. 42, 2667-2672.

Phillips, M.I., de Oliveira, E.M., 2008. Brain renin angiotensin in disease. J. Mol. Med. (Berl.) $86,715-722$.

Phillips, M.I., Kimura, B.K., 1986. Levels of brain angiotensin in the spontaneously hypertensive rat and treatment with ramiprilat. J. Hypertens. Suppl. 4, S391-S394.

Phillips, M.I., Sumners, C., 1998. Angiotensin II in central nervous system physiology. Regul. Pept. 78, 1-11.

Potts, P.D., Horiuchi, J., Coleman, M.J., Dampney, R.A., 2000. The cardiovascular effects of angiotensin-(1-7) in the rostral and caudal ventrolateral medulla of the rabbit. Brain Res. 877, 58-64.

Ruiz, P., Basso, N., Cannata, M.A., Taquini, A.C., 1990. The renin-angiotensin system in different stages of spontaneous hypertension in the rat (SHR). Clin. Exp. Hypertens. A $12,63-81$.

Safar, M., Chamiot-Clerc, P., Dagher, G., Renaud, J.F., 2001. Pulse pressure, endothelium function, and arterial stiffness in spontaneously hypertensive rats. Hypertension 38 1416-1421.

Santos, R.A., Simoes e Silva, A.C., Maric, C., Silva, D.M., Machado, R.P., de Buhr, I., HeringerWalther, S., Pinheiro, S.V., Lopes, M.T., Bader, M., Mendes, E.P., Lemos, V.S. Campagnole-Santos, M.J., Schultheiss, H.P., Speth, R., Walther, T., 2003. Angiotensin(1-7) is an endogenous ligand for the G protein-coupled receptor Mas. Proc. Natl. Acad. Sci. U. S. A. 100, 8258-8263.

Seyedabadi, M., Goodchild, A.K., Pilowsky, P.M., 2001. Differential role of kinases in brain stem of hypertensive and normotensive rats. Hypertension 38, 1087-1092.

Shibata, K., Komatsu, C., Misumi, Y., Furukawa, T., 1993. Developmental differences of angiotensinogen mRNA in the preoptic area between spontaneously hypertensive and age-matched Wistar-Kyoto rats. Brain Res. Mol. Brain Res. 19, 115-120.

Silva, A.Q., Schreihofer, A.M., 2011. Altered sympathetic reflexes and vascular reactivity in rats after exposure to chronic intermittent hypoxia. J. Physiol. 589, 1463-1476.

Silva, L.C., Fontes, M.A., Campagnole-Santos, M.J., Khosla, M.C., Campos Jr., R.R. Guertzenstein, P.G., Santos, R.A., 1993. Cardiovascular effects produced by microinjection of angiotensin-(1-7) on vasopressor and vasodepressor sites of the ventrolateral medulla. Brain Res. 613, 321-325.

da Silva, A.Q., Fontes, M.A., Kanagy, N.L., 2011. Chronic infusion of angiotensin receptor antagonists in the hypothalamic paraventricular nucleus prevents hypertension in a rat model of sleep apnea. Brain Res. 1368, 231-238.

Song, K., Allen, A.M., Paxinos, G., Mendelsohn, F.A., 1992. Mapping of angiotensin II receptor subtype heterogeneity in rat brain. J. Comp. Neurol. 316, 467-484.

Speth, R.C., Kim, K.H., 1990. Discrimination of two angiotensin II receptor subtypes with a selective agonist analogue of angiotensin II, p-aminophenylalanine6 angiotensin II. Biochem. Biophys. Res. Commun. 169, 997-1006.

Tagawa, T., Dampney, R.A., 1999. AT(1) receptors mediate excitatory inputs to rostral ventrolateral medulla pressor neurons from hypothalamus. Hypertension 34 , 1301-1307.

Tamura, K., Umemura, S., Nyui, N., Yamakawa, T., Yamaguchi, S., Ishigami, T., Tanaka, S. Tanimoto, K., Takagi, N., Sekihara, H., Murakami, K., Ishii, M., 1996. Tissue-specific regulation of angiotensinogen gene expression in spontaneously hypertensive rats. Hypertension 27, 1216-1223.

Tsuchihashi, T., Abe, I., Fujishima, M., 1994. Role of metabotropic glutamate receptors in ventrolateral medulla of hypertensive rats. Hypertension 24, 648-652.

Tsuchihashi, T., Kagiyama, S., Matsumura, K., Abe, I., Fujishima, M., 1999. Effects of chronic oral treatment with imidapril and TCV-116 on the responsiveness to angiotensin II in ventrolateral medulla of SHR. J. Hypertens. 17, 917-922.

Welch, W.J., Deng, X., Snellen, H., Wilcox, C.S., 1995. Validation of miniature ultrasonic transit-time flow probes for measurement of renal blood flow in rats. Am. J. Phys. 268, F175-F178.

Weyhenmeyer, J.A., Phillips, M.I., 1982. Angiotensin-like immunoreactivity in the brain of the spontaneously hypertensive rat. Hypertension 4, 514-523.

Wielbo, D., Sernia, C., Gyurko, R., Phillips, M.I., 1995. Antisense inhibition of hypertension in the spontaneously hypertensive rat. Hypertension 25, 314-319.

Willette, R.N., Punnen-Grandy, S., Krieger, A.J., Sapru, H.N., 1987. Differential regulation of regional vascular resistance by the rostral and caudal ventrolateral medulla in the rat J. Auton. Nerv. Syst. 18, 143-151.

Wright, J.W., Sullivan, M.J., Quirk, W.S., Batt, C.M., Harding, J.W., 1987. Heightened blood pressure and drinking responsiveness to intracerebroventricularly applied angiotensins in the spontaneously hypertensive rat. Brain Res. 420, 289-294.

Zhou, L.M., Shi, Z., Gao, J., Han, Y., Yuan, N., Gao, X.Y., Zhu, G.Q., 2010. Angiotensin-(1-7) and angiotension II in the rostral ventrolateral medulla modulate the cardiac sympathetic afferent reflex and sympathetic activity in rats. Pflugers Arch. 459, 681-688.

Zhu, D.N., Moriguchi, A., Mikami, H., Higaki, J., Ogihara, T., 1998. Central amino acids mediate cardiovascular response to angiotensin II in the rat. Brain Res. Bull. 45, 189-197. 